University of Nebraska - Lincoln

DigitalCommons@University of Nebraska - Lincoln

\title{
In Situ Characterization of Aluminum-Containing Mineral- Microorganism Aqueous Suspensions Using Scanning Transmission X-ray Microscopy
}

\author{
Tae Hyun Yoon \\ Stanford University \\ Stephen B. Johnson \\ Stanford University \\ Karim Benzerara \\ Stanford University \\ Colin S. Doyle \\ Stanford University \\ Tolek Tyliszczak \\ Lawrence Berkeley National Laboratory \\ See next page for additional authors \\ Follow this and additional works at: https://digitalcommons.unl.edu/usdoepub \\ Part of the Bioresource and Agricultural Engineering Commons
}

Yoon, Tae Hyun; Johnson, Stephen B.; Benzerara, Karim; Doyle, Colin S.; Tyliszczak, Tolek; Shuh, David K.; and Brown, Jr., Gordon E., "In Situ Characterization of Aluminum-Containing Mineral-Microorganism Aqueous Suspensions Using Scanning Transmission X-ray Microscopy" (2004). US Department of Energy Publications. 48.

https://digitalcommons.unl.edu/usdoepub/48

This Article is brought to you for free and open access by the U.S. Department of Energy at DigitalCommons@University of Nebraska - Lincoln. It has been accepted for inclusion in US Department of Energy Publications by an authorized administrator of DigitalCommons@University of Nebraska - Lincoln. 


\section{Authors}

Tae Hyun Yoon; Stephen B. Johnson; Karim Benzerara; Colin S. Doyle; Tolek Tyliszczak; David K. Shuh; and Gordon E. Brown, Jr. 


\title{
Letters
}

\section{In Situ Characterization of Aluminum-Containing Mineral-Microorganism Aqueous Suspensions Using Scanning Transmission X-ray Microscopy}

\author{
Tae Hyun Yoon,${ }^{\dagger}$ Stephen B. Johnson, ${ }^{\dagger}$ Karim Benzerara ${ }^{\dagger}$ Colin S. Doyle ${ }^{\dagger}$ \\ Tolek Tyliszczak, $\stackrel{\ddagger}{\ddagger}$ David K. Shuh,$\stackrel{\ddagger}{ }$ and Gordon E. Brown, Jr. ${ }^{*}, \dagger, \S$ \\ Surface \& Aqueous Geochemistry Group, Department of Geological \& Environmental Sciences, \\ Stanford University, Stanford, California 94305-2115, Chemical Sciences Division, Lawrence \\ Berkeley National Laboratory, Berkeley, California 94720, and Stanford Synchrotron \\ Radiation Laboratory, SLAC, 2575 Sand Hill Road, \\ Menlo Park, California 94025
}

Received June 10, 2004. In Final Form: September 9, 2004

\begin{abstract}
In situ characterization of colloidal particles under hydrous conditions is one of the key requirements for understanding their state of aggregation and impact on the transport of pollutants in aqueous environments. Scanning transmission X-ray microscopy (STXM) is one of the few techniques that can satisfy this need by providing element- and chemical-state-specific 2-D maps at a spatial resolution better than $50 \mathrm{~nm}$ using soft X-rays from synchrotron radiation wiggler or undulator sources tuned to the absorption edges of different elements. X-ray absorption near-edge structure (XANES) spectra can also be collected simultaneously at a similar spatial resolution and can provide phase identification in many cases. In this study, we report STXM images and XANES spectroscopy measurements at or above the Al K-edge $(E=$ $1559.6 \mathrm{eV}$ ) of various $\mathrm{Al}$-containing minerals and synthetic oxides $\left[\alpha-\mathrm{Al}_{2} \mathrm{O}_{3}\right.$ (corundum), $\gamma-\mathrm{Al}_{2} \mathrm{O}_{3}, \gamma-\mathrm{AlOOH}$ (boehmite), $\alpha-\mathrm{Al}(\mathrm{OH})_{3}$ (bayerite), $\mathrm{KAl}_{2}\left(\mathrm{AlSi}_{3} \mathrm{O}_{10}\right)(\mathrm{OH})_{2}$ (muscovite), $(\mathrm{Al}, \mathrm{Mg})_{8}\left(\mathrm{Si}_{4} \mathrm{O}_{10}\right)_{4}(\mathrm{OH})_{8} \cdot n \mathrm{H}_{2} \mathrm{O}$ (montmorillonite), and $\mathrm{Mg}_{6} \mathrm{Al}_{2}(\mathrm{OH})_{16} \mathrm{CO}_{3} \cdot 4 \mathrm{H}_{2} \mathrm{O}$ (hydrotalcite)] and demonstrate the capability of this spectromicroscopic tool to identify different Al-containing mineral colloids in multiphase mixtures in aqueous solution. We also demonstrate that STXM imaging at or above the $\mathrm{C} \mathrm{K}$-edge $(E=284.2 \mathrm{eV})$ and $\mathrm{Al} \mathrm{K}$-edge can provide unique information on the interactions between bacteria and Al-containing nanoparticles in aqueous suspensions. STXM images of a mixture of Caulobacter crescentus and montmorillonite and corundum particles just above the $\mathrm{C}$ and $\mathrm{Al}$ K-edges show that the mineral particles and bacteria are closely associated in aggregates, which is likely due to the binding of bacteria to clay and corundum particles by extracellular polysaccharides.
\end{abstract}

\section{Introduction}

Knowledge of the identity and stability of natural colloids under hydrous conditions is essential for understanding their ability to transport pollutants in natural waters. ${ }^{1-3}$ Due to their ubiquitous presence in Earth's

* Corresponding author. Phone: 650-723-9168. Fax: 650-7252199. E-mail: gordon@pangea.stanford.edu.

† Stanford University.

$\$$ Lawrence Berkeley National Laboratory.

$\S$ Stanford Synchrotron Radiation Laboratory. crust, aluminosilicate minerals such as clays are major components of natural inorganic colloids in many natural settings. ${ }^{4}$ However, to our knowledge, there have been no spectroscopic or microscopic characterization studies of

(1) McCarthy, J. F.; Zachara, J. M. Environ. Sci. Technol. 1989, 23 496-502.

(2) Gustafsson, O.; Gschwend, P. M. Limnol. Oceanogr. 1997, 42, $519-528$.

(3) Grolimund, D.; Borkovec, M.; Barmettler, K.; Sticher, H. Environ. Sci. Technol. 1996, 30, 3118-3123.

(4) Buffle, J.; Wilkinson, K. J.; Stoll, S.; Filella, M.; Zhang, J. W. Environ. Sci. Technol. 1998, 32, 2887-2899. 
Table 1. Names, Formulas, Al Coordination Numbers, and Major XANES Peak Positions of the Al-Containing Minerals Used in This Study

\begin{tabular}{|c|c|c|c|}
\hline mineral name (source) & formula & $\mathrm{Al}$ coordination no. & $\begin{array}{l}\text { Al K-edge XANES } \\
\text { peak positions }(\mathrm{eV})\end{array}$ \\
\hline corundum (Sumitomo Co. Ltd.) & $\alpha-\mathrm{Al}_{2} \mathrm{O}_{3}$ & 6 & $1567.5,1571.5$ \\
\hline gamma alumina (Sumitomo Co. Ltd.) & $\gamma-\mathrm{Al}_{2} \mathrm{O}_{3}$ & 4,6 & $1565.4,1567.5,1570.5$ \\
\hline boehmite (Condea Chemie $\mathrm{GmBH}$ ) & $\gamma-\mathrm{AlOOH}$ & 6 & $1567.8,1570.2,1571.8$ \\
\hline bayerite (Condea Chemie $\mathrm{GmBH}$ ) & $\alpha-\mathrm{Al}(\mathrm{OH})_{3}$ & 6 & $1567.4,1570.2$ \\
\hline muscovite (Stanford Mineral Collection) & $\mathrm{KAl}_{2}\left(\mathrm{AlSi}_{3} \mathrm{O}_{10}\right)(\mathrm{OH})_{2}$ & 4,6 & $1565.3,1567.7,1570.4$ \\
\hline hydrotalcite (Condea Chemie GmBH) & $\mathrm{Mg}_{6} \mathrm{Al}_{2}(\mathrm{OH})_{16} \mathrm{CO}_{3} \cdot 4 \mathrm{H}_{2} \mathrm{O}$ & 6 & $1567.7,1571.4$ \\
\hline montmorillonite (Source Clays Repository) & $(\mathrm{Al}, \mathrm{Mg})_{8}\left(\mathrm{Si}_{4} \mathrm{O}_{10}\right)_{4}(\mathrm{OH})_{8} \cdot 12 \mathrm{H}_{2} \mathrm{O}$ & 6 & $1567.7,1570.8$ \\
\hline
\end{tabular}

Al-containing colloidal systems in the presence of bulk water mainly due to the lack of appropriate methods for probing submicron-sized Al-containing particles in hydrous environments.

Synchrotron-based scanning transmission X-ray microscopy (STXM) is one of the few methods capable of characterizing colloidal particles $>30 \mathrm{~nm}$ in diameter in the presence of water and/or under atmospheric conditions. ${ }^{5-11}$ However, due to the limited energy ranges available on the seven other currently available STXM beamlines at synchrotron radiation sources worldwide [National Synchrotron Light Source (NSLS), BL X1A1 $(250-500 \mathrm{eV})$ and X1A2 (250-1000 eV); Advanced Light Source (ALS), BL 5.3.2 (250-700 eV); Bessy II, Germany: ID12 (250-600 eV); European Synchrotron Radiation Facility (ESRF), BL ID $21(2000-8000 \mathrm{eV})$; Advance Photon Source (APS): 2-ID-B (1-4 keV); Pohang Accelerator Laboratory (PAL, South Korea), BL 8A (250$1000 \mathrm{eV}$ )] plus several others that are in varying stages of development, soft X-ray spectromicroscopy studies using STXM have generally been limited to the K-edges of light elements (e.g., C, N, and O $)^{5-9}$ or the L-edges or K-edges of alkaline earth (e.g., Ca) and first-row transition metals (e.g., Cr, Mn, and Fe).10,11 Recently, a new STXM end station has been built and commissioned on the 11.0.2.2 branch line of an elliptically polarized undulator beamline (11.0.2) at the Advanced Light Source (ALS) at Lawrence Berkeley National Laboratory and has been optimized for applications to molecular environmental science, interface science, microbiology, and heterogeneous catalysis. It offers a wider energy range in the soft-X-ray/ vacuum ultraviolet energy region $(E=130-2100 \mathrm{eV})$ than what is available at other existing STXM facilities in addition to excellent spatial $(<50 \mathrm{~nm})$ and energy resolution $(\sim 0.3 \mathrm{eV})$ at the Al K-edge. ${ }^{12}$ This new STXM facility enables the characterization of mineral particles $30 \mathrm{~nm}$ or greater in diameter using the K-edges of $\mathrm{B}, \mathrm{C}, \mathrm{N}, \mathrm{O}, \mathrm{Na}$, $\mathrm{Mg}, \mathrm{Al}$, and $\mathrm{Si}$ and the L-edges of $\mathrm{P}, \mathrm{S}, \mathrm{Cl}, \mathrm{K}, \mathrm{Ca}, \mathrm{Sc}, \mathrm{Ti}$, $\mathrm{V}, \mathrm{Cr}, \mathrm{Mn}, \mathrm{Fe}, \mathrm{Co}, \mathrm{Ni}, \mathrm{Cu}, \mathrm{Zn}, \mathrm{Ga}, \mathrm{Ge}, \mathrm{As}, \mathrm{Se}, \mathrm{Br}, \mathrm{Rb}$, and Sr under hydrous conditions. This list includes all major elements in Earth's crust as well as in biological organisms, with the exception of $\mathrm{H}$. In this study, we have used this new STXM end station to investigate synthetic Al-

(5) Myneni, S. C. B. Rev. Mineral. Geochem. 2002, 49, 485-579.

(6) Myneni, S. C. B.; Brown, J. T.; Martinez, G. A.; Meyer-Llse, W. Science 1999, 286, 1335-1337.

(7) Hitchcock, A. P. J. Synchrotron Radiat. 2001, 8, 66-71.

(8) Rothe, J.; Denecke, M. A.; Dardenne, K. J. Colloid Interface Sci. 2000, 231, 91-97.

(9) Russell, L. M.; Maria, S. F.; Myneni, S. C. B. Geophys. Res. Lett. 2002, 29, 1779-1782.

(10) Pecher, K.; McCubbery, D.; Kneedler, E.; Rothe, J.; Bargar, J.; Meigs, G.; Cox, L.; Nealson, K.; Tonner, B. Geochim. Cosmochim. Acta 2003, 67, 1089-1098.

(11) Buckley, C. J.; Khaleque, N.; Bellamy, S. J.; Robins, M.; Zhang, X. J. Phys. IV 1997, 7, 83-90.

(12) Tyliszczak, T.; Warwick, T.; Kilcoyne, A. L. D.; Fakra, S.; Shuh, D. K.; Yoon, T. H.; Brown, G. E., Jr.; Andrews, S.; Chembrolu, V.; Strachan, J.; Acremann., Y. Proceedings of the 2003 Synchrotron Radiation Instrumen. Meeting, San Francisco, CA, 2004; 1356-1359. containing mineral colloid systems, including those with bacteria and water present, as a test of its capabilities. STXM images near the Al K-edge $(E=1565.4-1571.8$ $\mathrm{eV}$ ) and $\mathrm{Al} \mathrm{K}$-edge X-ray absorption near-edge structure (XANES) spectra have been measured for synthetic mineral colloid mixtures under hydrous conditions and analyzed using Al K-XANES spectra of selected reference minerals. In addition, bacteria-mineral suspensions in aqueous solution have been imaged just above the $\mathrm{C} K$-edge $(E=288.8 \mathrm{eV})$ and Al K-edge $(E=1571.6 \mathrm{eV})$ in a study of bacteria-mineral colloid interactions.

\section{Experimental Details}

Table 1 summarizes the names, sources, formulas, $\mathrm{Al}$ coordination numbers, and major Al K-XANES peak positions of the Al-containing reference minerals and synthetic oxides utilized in this study. Dry reference samples were prepared for STXM analysis by dispersing the minerals in Milli-Q grade water $(\sim 1$ $\mathrm{g} / \mathrm{L}$ ) and then drying $\sim 1 \mu \mathrm{L}$ of each suspension on a $100 \mathrm{~nm}$ thick $\mathrm{Si}_{3} \mathrm{~N}_{4}$ membrane (Silson Ltd.), which had been previously glued on the STXM sample holder. Aqueous suspensions of Alcontaining mineral mixtures $(\sim 1 \mathrm{~g} / \mathrm{L}$ for each mineral) were prepared in $0.01 \mathrm{M} \mathrm{NaCl}$, with the $\mathrm{pH}$ of the solution being adjusted to 6.0 by adding $0.1 \mathrm{M} \mathrm{NaOH}$ and $\mathrm{HCl}$. Approximately $1 \mu \mathrm{L}$ of each suspension was sandwiched between two $100 \mathrm{~nm}$ thick $\mathrm{Si}_{3} \mathrm{~N}_{4}$ membranes, which were then sealed with epoxy resin to maintain a fully hydrated environment during STXM analysis. The STXM sample chamber is He-filled to minimize attenuation of the soft X-rays. To check the correspondence between the shapes of mineral particles and the shapes obtained from STXM images, high-resolution scanning electron microscopy (FEI, Sirion) images were taken of the dried corundum particles used in the present study.

For the mineral-bacteria mixtures, we utilized the aquatic bacterium Caulobacter crescentus, which is found in many natural environments and has been used as a model for microbial adhesion studies. ${ }^{13}$ The culture medium utilized was a sterile minimal medium [consisting of $\mathrm{Na}_{2} \mathrm{HPO}_{4}(130 \mathrm{mM}), \mathrm{KH}_{2} \mathrm{PO}_{4}$ (7.8 mM), $\mathrm{NH}_{4} \mathrm{Cl}(9.3 \mathrm{mM}), \mathrm{MgSO}_{4}(0.5 \mathrm{mM}), \mathrm{CaCl}_{2}(0.5 \mathrm{mM})$, glucose $(2 \mathrm{~g} / \mathrm{L}), \mathrm{FeSO}_{4}(0.01 \mathrm{mM})$, and ethylenediaminetetraacetate (EDTA) $(0.01 \mathrm{mM})]$. Mineral powders were autoclaved separately at $121^{\circ} \mathrm{C}$ for $20 \mathrm{~min}$ and added to the culture medium before inoculation with $C$. crescentus cells. Cells were grown for $48 \mathrm{~h}$ in the presence of corundum and montmorillonite particles at $30^{\circ} \mathrm{C}$. During this process, all samples were constantly shaken (200 rpm). Wet samples were mounted by sandwiching and sealing each mineral-bacteria-water mixture between two $\mathrm{Si}_{3} \mathrm{~N}_{4}$ membranes.

STXM studies were performed at ALS branch line 11.0.2.2 with the synchrotron storage ring operating at an energy of 1.9 $\mathrm{GeV}$ and a stored current of 200-400 mA. Energy calibration was checked daily against the first major XANES peak in the corundum Al K-edge XANES spectrum, which was previously determined relative to the first inflection point in the K-edge XANES of aluminum metal $(E=1559.0 \mathrm{eV}) .{ }^{14}$ The detector used in all measurements reported in this study was a photomultiplier tube with a phosphor scintillator. Image stacks or line scans of

(13) Nivens, D. E.; Chambers, J. Q.; Anderson, T. R.; Tunlid, A.; Smit, J.; White, D. C. J. Microbiol. Methods 1993, 17, 199-213.

(14) Doyle, C. S.; Traina, S. J.; Ruppert, H.; Kendelewicz, T.; Rehr, J. J.; Brown, G. E., Jr. J. Synchrotron Radiat. 1999, 6, 621-623. 

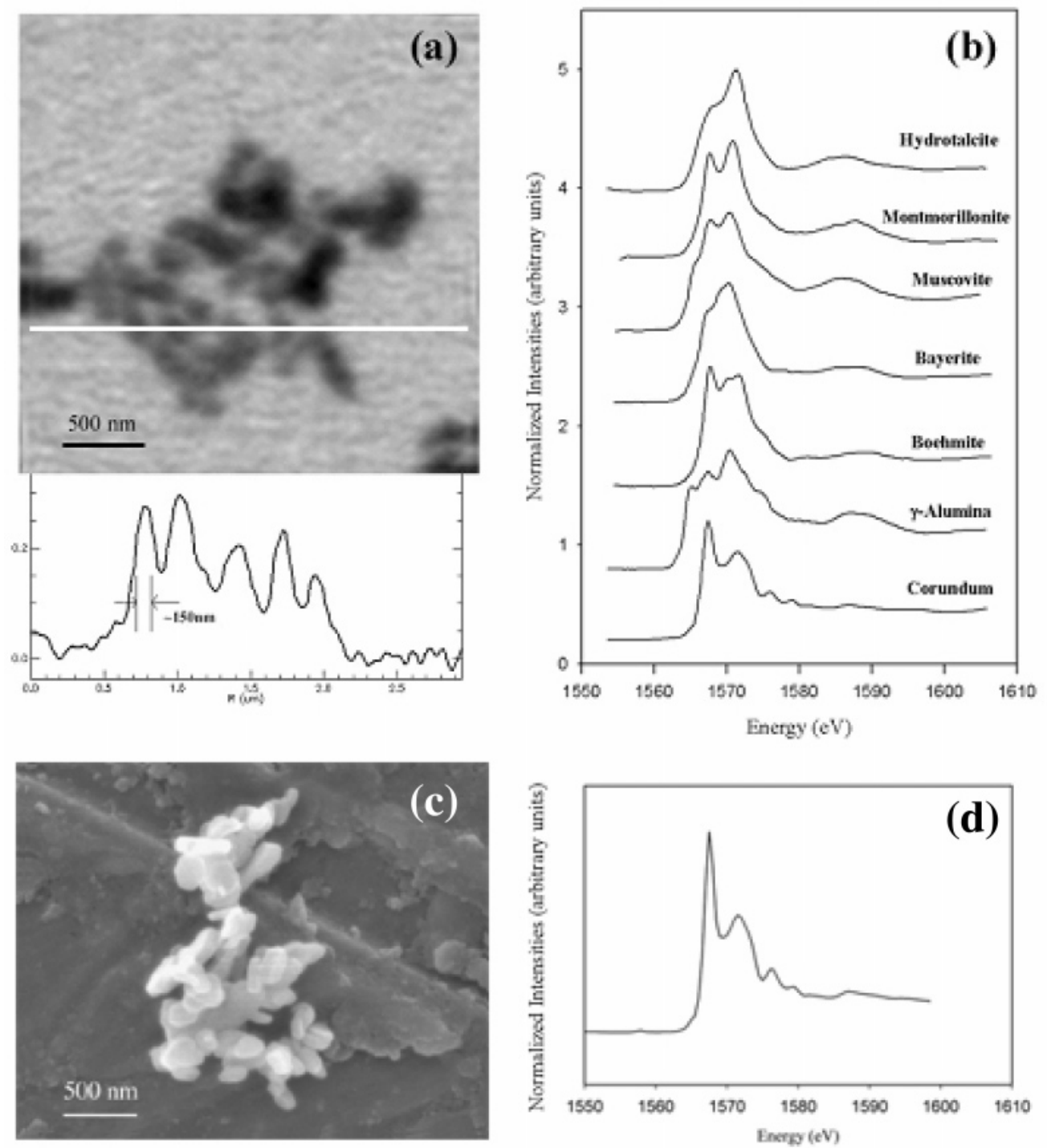

Figure 1. (a) STXM image and horizontal optical density cross section of corundum particles in aqueous solution taken at 1567.5 $\mathrm{eV}$, (b) Al K-edge XANES spectra of seven Al-containing minerals, (c) high-resolution SEM image of dry corundum particles in a vacuum of $10^{-6}$ Torr, and (d) Al K-edge XANES spectrum of a dry corundum single crystal sample [(0001) orientation] measured using a conventional synchrotron beamline (SSRL BL 3-3) under ultrahigh vacuum conditions $\left(10^{-9}\right.$ Torr).$^{14}$

reference Al-(oxy)hydroxide minerals and hydrous mineral mixtures were performed to collect $\mathrm{Al} \mathrm{K}$-edge XANES spectra; stacks of images or lines were taken by scanning in the $x-y$ direction (image stack) or the $x$ direction (line scan) of selected sample areas at each energy increment over the energy range of interest (1555-1605 eV); here, $x$ refers to the horizontal direction, $y$, to the vertical direction, and the $x-y$ plane, to the plane perpendicular to the X-ray beam direction. Normalization and background correction of the $\mathrm{Al} \mathrm{K-edge} \mathrm{XANES} \mathrm{spectra} \mathrm{were}$ performed by dividing each spectrum by a second spectrum from an $\mathrm{Al}$-free location on the same sample. Possible sample changes caused by X-ray radiation were also monitored, but no significant changes in the $\mathrm{Al} \mathrm{K}$-edge XANES spectra were observed during the course of these measurements. The effect of hydration on $\mathrm{Al}$ K-edge XANES spectra was also monitored by comparing spectra from dried and hydrated minerals (e.g., corundum, boehmite, and montmorillonite), but no significant spectral differences were found between the dried and hydrated samples. However, significant particle movements were occasionally observed during long image stack measurements of wet samples, probably due to water advection caused by local heating of the aqueous solution. While minor movements of mineral particles can be easily corrected by realignment procedures, the time for image stack acquisition was optimized to minimize the influence of larger advection-induced particle movements on the XANES spectra.
AXis2000 software (ver2.1n) ${ }^{15}$ was used to align image stacks and extract XANES spectra from image stack or line scan measurements.

\section{Results and Discussion}

3.1. Al K-edge XANES Spectra of Reference Mineral Particles. Figure 1 presents an Al K-edge STXM image of corundum particles in water as well as $\mathrm{Al} \mathrm{K}$-edge XANES spectra of seven Al-containing model compounds and illustrates the spatial and energy resolutions that can be achieved at the $\mathrm{Al} \mathrm{K}$-edge with current zone plates. Figure 1a shows a STXM image $(E=1567.5 \mathrm{eV})$ of corundum particle clusters under hydrous conditions. The horizontal cross section showing optical density contrast below the STXM image clearly indicates that there are at least five particles along the cross-cutting line, each with a diameter of $\sim 150 \mathrm{~nm}$. As a test of the ability of STXM to provide accurate shapes of mineral particles in aqueous suspensions, we compare a high-resolution scanning electron microscopy (SEM) image of dry corundum particles (Figure 1c) with the STXM image of a different

(15) Hitchcock, A. P. http://unicorn.mcmaster.ca/aXis2000.html. 


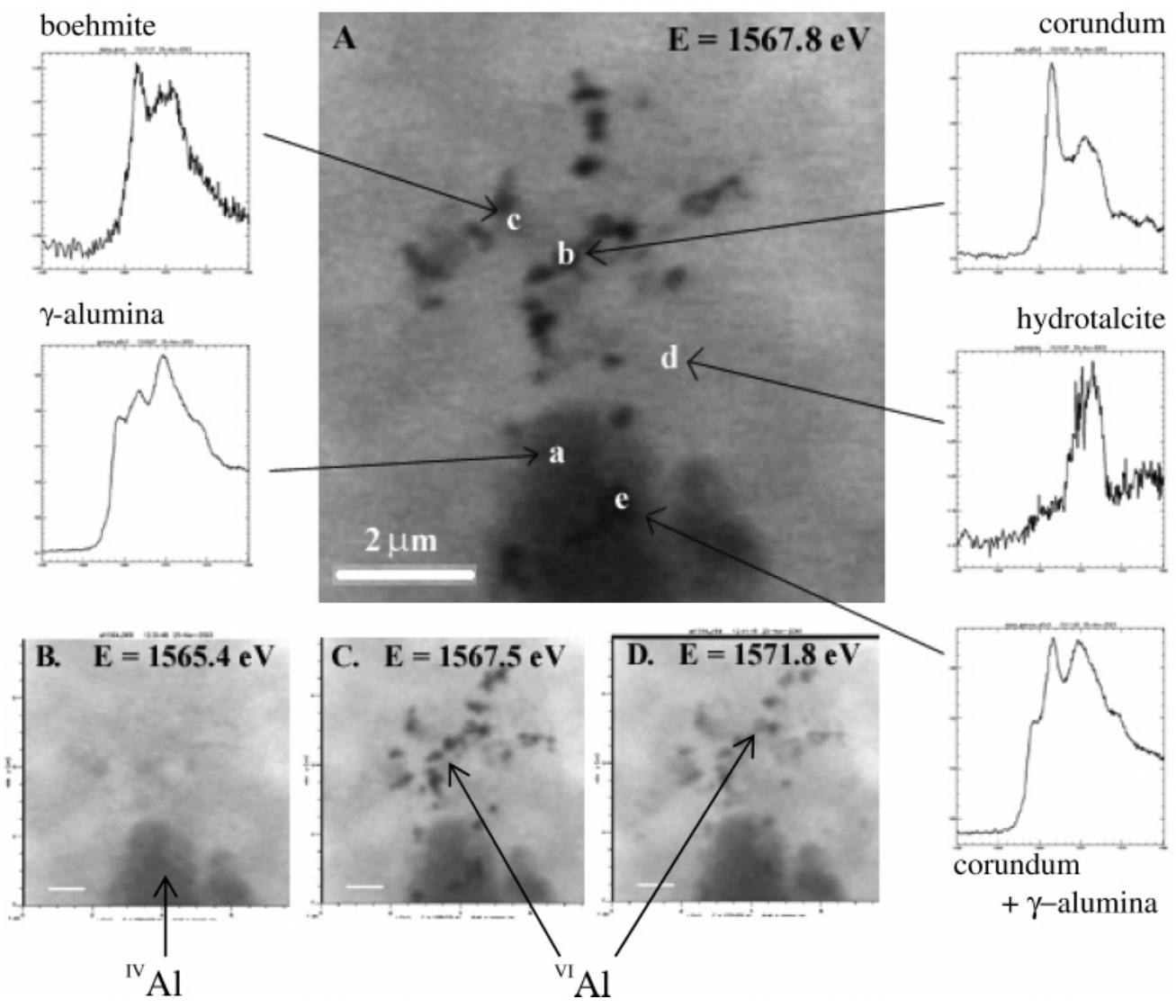

Figure 2. STXM image and Al K-edge XANES spectra of mineral particle mixtures under hydrous conditions measured at (A) $E=1567.8 \mathrm{eV}$, (B) $E=1565.4 \mathrm{eV}$ (energy corresponds to the first peak of the $\gamma-\mathrm{Al}_{2} \mathrm{O}_{3}$ XANES spectrum), (C) $E=1567.5 \mathrm{eV}$ (energy corresponds to the first peak of the corundum XANES spectrum), and (D) $E=1571.8 \mathrm{eV}$ (energy corresponds to the third peak of the boehmite XANES spectrum). Each XANES spectrum was collected from the areas indicated by a, b, c, d, and e.

cluster of corundum particles in an aqueous suspension (Figure 1a). The SEM image shows that most corundum particles in our sample have ellipsoidal shapes or are hexagonal plates. A STXM image of a different cluster of corundum crystals in aqueous solution at a similar spatial scale (Figure 1a) shows ellipsoidal or rod-shaped particles. It is difficult to obtain additional details about particle morphology from the STXM image alone.

Al K-edge XANES spectra of a variety of Al-containing reference minerals, including the corundum particles shown in Figure 1a, are presented in Figure 1b. These spectra show well-resolved, distinct features and are in good agreement with spectra from previous Al K-edge XANES studies of similar mineral samples performed under ultrahigh vacuum (UHV) conditions using total electron yield measurements (see Figure 1d). ${ }^{14,16-21}$ The $\mathrm{Al} \mathrm{K}$-edge XANES spectrum of $\gamma-\mathrm{Al}_{2} \mathrm{O}_{3}$, in which about one-third of the $\mathrm{Al}$ is 4-coordinated and two-thirds is 6-coordinated (Figure 1, Table 1), shows three major features centered at $1565.4,1567.5$, and $1570.5 \mathrm{eV}$. In contrast, the spectrum of $\alpha-\mathrm{Al}_{2} \mathrm{O}_{3}$, which contains only 6 -coordinated $\mathrm{Al}$, has two main features at 1567.5 and $1571.5 \mathrm{eV}$. The feature at $1565.4 \mathrm{eV}$ in the spectrum of

(16) Brown, G. E., Jr.; Dikman, F. D.; Waychunas, G. A. SSRL Report 1983, 83/01, 148-149.

(17) McKeown, D. A.; Waychunas, G. A.; Brown, G. E., Jr. J. NonCryst. Solids 1985, 74, 349-371.

(18) Ildefonse, P.; Kirkpatrick, R. J.; Montez, B.; Calas, G.; Flank. A.-M.; Lagarde, P. Clays Clay Miner. 1994, 42, 276-287.

(19) Ildefonse, P.; Calas, G.; Flank, A.-M.; Lagarde, P.Nucl. Instrum. Methods Phys. Res. 1995, B97, 172-175.

(20) Cabaret, D.; Sainctavitt, P.; Ildefonse, P.; Flank, A.-M. J. Phys.: Condens. Matter 1996, 8, 3691-3704.

(21) Ildefonse, P.; Cabaret, D.; Sainctavit, P.; Calas, G.; Flank, A.; Lagarde, P. Phys. Chem. Miner. 1998, 25, 112-121.
$\gamma-\mathrm{Al}_{2} \mathrm{O}_{3}$ is indicative of 4-coordinated $\mathrm{Al}$, whereas the features at 1567.5 and $1570.5 \mathrm{eV}$ are indicative of 6 -coordinated $\mathrm{Al}$, as noted in past $\mathrm{Al} \mathrm{K}$-edge XANES studies of other Al-containing materials. ${ }^{14,16-21}$ The other Al-containing minerals examined here, with the exception of muscovite, contain only 6-coordinated $\mathrm{Al}$ and also show two major features at similar positions with average values of $1567.6 \pm 0.2$ and $1570.7 \pm 0.7 \mathrm{eV}$, but with different peak shapes characteristic of each mineral phase. Muscovite, which contains both 4- and 6-coordinated $\mathrm{Al}$ displays an extra spectral feature at $1565.3 \mathrm{eV}$, similar to $\gamma-\mathrm{Al}_{2} \mathrm{O}_{3}$. Additional features in the $\mathrm{Al} \mathrm{K}$-edge XANES spectra of these solids are due to multiple scattering caused by small differences in the medium-range $(<5 \AA)$ coordination environment of $\mathrm{Al}$ in each solid. Thus, $\mathrm{Al} \mathrm{K}$-edge XANES spectra can be used as a probe of $\mathrm{Al}$ coordination numbers in colloidal suspensions of mineral particles and can additionally serve as a "fingerprint" for different Alcontaining phases. It is worth noting that most of the spectra shown in Figure 1b were collected for single particles in a substantially shorter period of time $(<5 \mathrm{~min})$ than comparable spectra collected on bending magnet synchrotron radiation sources using conventional detection methods such as total electron yield.

3.2. Al K-edge STXM Image Stack Analysis of Mixed Mineral Colloid Suspensions. STXM images collected for a mixed aqueous suspension consisting of four finely ground Al-containing minerals $\left(\gamma-\mathrm{Al}_{2} \mathrm{O}_{3}\right.$, corundum, boehmite, and hydrotalcite) at $\mathrm{pH} 6.0$ are shown in Figure 2. STXM image stacks were collected over the Al K-edge energy range. Figure 2 compares STXM images collected at several different energies $(\mathrm{A}-\mathrm{D})$ and XANES 
spectra extracted from different positions $(\mathrm{a}-\mathrm{e})$ of these image stacks.

As can be seen from Figure 2B-D, STXM images collected at different energies can be used to distinguish different Al-containing mineral phases, especially aluminum minerals with different coordination numbers. The image collected at $E=1565.4 \mathrm{eV}$ (corresponding to the first peak of the $\gamma-\mathrm{Al}_{2} \mathrm{O}_{3}$ XANES spectrum) (Figure 2B) shows only several $\gamma-\mathrm{Al}_{2} \mathrm{O}_{3}$ particles $(2-3 \mu \mathrm{m}$ in diameter $)$. As the incident X-ray energy is increased to the positions of the corundum and boehmite Al K-edges (1567.5 and $1571.8 \mathrm{eV}$, as shown in Figure 2C and D, respectively), a large number of small particles (100-200 $\mathrm{nm}$ in diameter) become apparent in the mapped area. These small particles most likely consist of corundum, boehmite, and/ or hydrotalcite. However, without XANES spectral processing and comparison (or deconvolution) with reference spectra, it is difficult to distinguish among particles of different minerals with the same $\mathrm{Al}$ coordination number from the images collected at different energies alone.

Further processing of image stacks and resulting XANES spectra was performed to distinguish the particles shown in Figure 2C and D. Figure 2A shows a STXM image of the same mineral colloid mixture taken at an incident X-ray energy of $1567.8 \mathrm{eV}$. Also shown in Figure 2 are $\mathrm{Al}$ K-edge XANES spectra corresponding to regions $\mathbf{a}-\mathbf{e}$. XANES spectra from region a showed spectral features that are the same as those of the $\gamma-\mathrm{Al}_{2} \mathrm{O}_{3}$ reference material (Figure 1), while the XANES spectra from regions $\mathbf{b}$ and $\mathbf{c}$ are very similar to those of the corundum and boehmite reference materials, respectively (Figure 1). Although we added the same concentrations of each reference mineral phase $(1 \mathrm{~g} / \mathrm{L})$ to this colloidal suspension, hydrotalcite was rarely observed in this sample, except in the small area around $\mathbf{d}$, as indicated by the peak maximum at $1571.4 \mathrm{eV}$. This is probably due to the relatively low aluminum content $(\sim 9 \mathrm{wt} \%)$ in this mineral phase and the very fine grain size and/or the dispersed nature of the hydrotalcite under the aqueous conditions utilized in our study. We also observe unusual XANES features in region $\mathbf{e}$, which can be explained by a composite spectrum of $\alpha-\mathrm{Al}_{2} \mathrm{O}_{3}$ and $\gamma-\mathrm{Al}_{2} \mathrm{O}_{3}$, resulting from clusters of small $\alpha-\mathrm{Al}_{2} \mathrm{O}_{3}$ particles $(\sim 150 \mathrm{~nm})$ associated with a larger $\gamma-\mathrm{Al}_{2} \mathrm{O}_{3}$ particle in the sample volume probed by the X-ray beam.

3.3. Comparisons of $\mathrm{C}$ and $\mathrm{Al} \mathrm{K}$-edge Images from Mineral-Bacteria Suspensions. Figures 3 and 4 show STXM images obtained in situ from a prepared aqueous suspension of mineral particles (corundum and montmorillonite) and the bacterium Caulobacter crescentus, which is intended to mimic the complexity of natural biocolloids. As can be seen in Figure 3, although there are wide variations in the sizes of bacteria-mineral clusters, a close association of $C$. crescentus and mineral particles is common over a wide sample area. Among these $C$. crescentus-mineral clusters, we selected two representative clusters (Figure 3, areas a and b) and show their magnified images in Figure 4. Parts a and c of Figure 4 show STXM images taken near the C K-edge $(288.8 \mathrm{eV})$, whereas parts $b$ and $d$ of Figure 4 show STXM images of the same areas taken near the $\mathrm{Al} \mathrm{K}$-edge $(1571.6 \mathrm{eV})$. The C K-edge STXM images show rod-shaped bacteria $(\approx 2$ $\mu \mathrm{m}$ long and $0.5 \mu \mathrm{m}$ wide) as well as submicron-sized dark spots within the bacteria, which are consistent with the polyhydroxybutyrate (PHB) granules observed in $C$. crescentus by TEM. ${ }^{22}$ These granules are used by the

(22) Poindexter, J. S.; Pujara, K. P.; Staley, J. T. Appl. Environ. Microbiol. 2000, 66, 4105-4111.

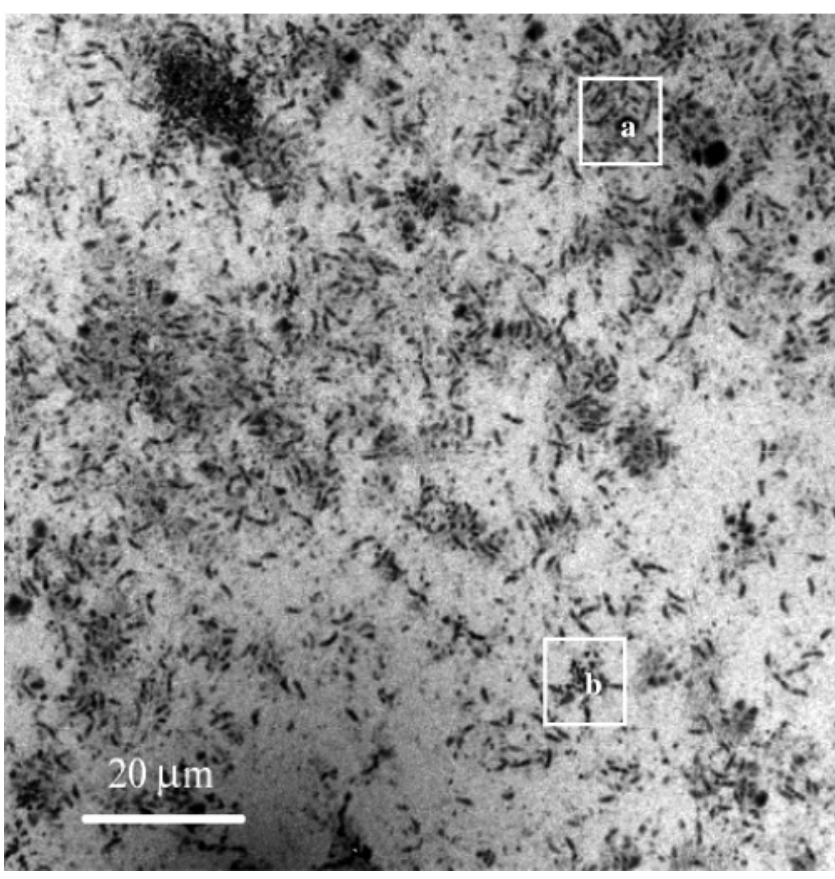

Figure 3. STXM image $(90 \mu \mathrm{m} \times 90 \mu \mathrm{m})$ of a Caulobacter crescentus - mineral mixture (corundum and montmorillonite) in an aqueous suspension measured in the vicinity of the $\mathrm{C}$ K-edge $(E=288.8 \mathrm{eV})$. The outlined areas labeled a and b are shown at higher magnification at the $\mathrm{C}$ and $\mathrm{Al} \mathrm{K}$-edges, respectively, in Figure 4.

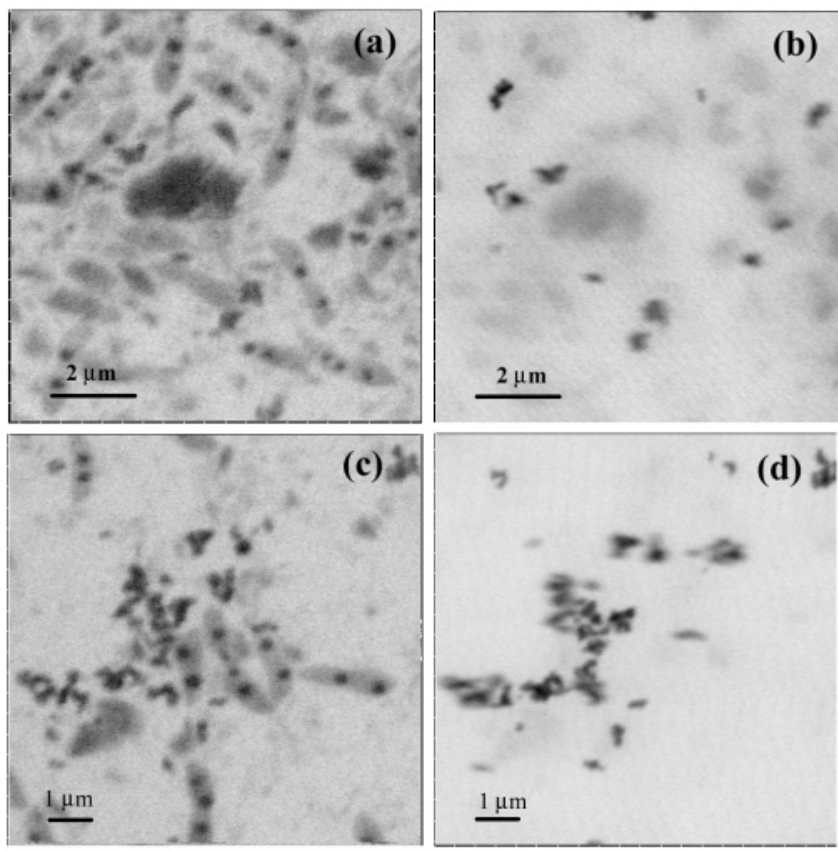

Figure 4. STXM images of a Caulobacter crescentus-mineral mixture (corundum and montmorillonite) in an aqueous suspension measured in the vicinity of (a and c) the C K-edge $(E=288.8 \mathrm{eV})$ and $(\mathrm{b}$ and d) the Al K-edge $(E=1571.6 \mathrm{eV})$. Parts $\mathrm{a}$ and $\mathrm{b}$ are higher magnification images from area $\mathrm{a}$ in Figure 3, and parts $\mathrm{c}$ and $\mathrm{d}$ are higher magnification images from area $\mathrm{b}$ in Figure 3 .

bacterium as carbon and energy reserves. In $\mathrm{Al} \mathrm{K}$-edge images (Figure $4 \mathrm{~b}$ and d), these bacterial components (i.e., cells and dark spots within cells) are not visible, while many dark patches observed outside the bacterial cells in Figure $4 \mathrm{a}$ and $\mathrm{c}$ are still visible in Figure $4 \mathrm{~b}$ and $\mathrm{d}$, suggesting that these dark patches are rich in aluminum. In the C K-edge spectra of the bacteria (not shown), the 
feature at $288.8 \mathrm{eV}$ is characteristic of extracellular polysaccharides (EPS) and the peak at $288.2 \mathrm{eV}$ is characteristic of proteins. ${ }^{24}$ However, there is some overlap of the these peaks, so the images in Figure $4 \mathrm{a}$ and $\mathrm{c}$ are due to both EPS and proteins. We do not report C K-edge spectra in this study because of our inability to obtain an appropriate $I_{0}$ spectrum on a portion of the sample not containing bacteria or EPS.

STXM images at the Al K-edge (see Figure 4b and d) allow the above carbonaceous particles to be distinguished from the Al-containing colloidal components. Furthermore, $\mathrm{Al} \mathrm{K}$-edge XANES analyses of the dark and gray areas shown in Figure $4 \mathrm{~b}$ confirm that the small $(<500 \mathrm{~nm}$ in diameter) dark clusters in Figure $4 \mathrm{~b}$ and $\mathrm{d}$ are corundum particle clusters, whereas the larger and more diffuse objects ( $\sim 2 \mu \mathrm{m}$ in diameter) are montmorillonite particles. It is further observed in the STXM images that the bacterial cells and mineral particles are closely associated, forming relatively large bacteria-mineral flocs. Interestingly, however, the bacterial cell wall surfaces are not in direct contact with the corundum or montmorillonite particle surfaces in the aqueous solutions used in this study ( $\mathrm{pH} 7$, minimal growth medium). Because production of EPS and attachment to various surfaces via an adhesive holdfast organelle located at the end of the stalk has previously been observed in C. crescentus, ${ }^{24,25}$ we suggest that these adhesive holdfast organelles as well as EPS produced by $C$. crescentus bind the bacteria to the clay and corundum particles. The formation of EPSmediated flocs is likely to have a significant impact on the physical stability of colloidal particles. ${ }^{26}$

\section{Conclusions}

Scanning transmission X-ray microscopy (STXM) on a newly commissioned end station on branch line 11.0.2.2 at the Advanced Light Source has been utilized to characterize mixtures of Al-containing mineral colloids

(23) Lawrence, J. R.; Swerhone, G. D. W.; Leppard, G. G.; Araki, T.; Zhang, X.; West, M. M.; Hitchcock, A. P.Appl. Environ. Microbiol. 2003, $69,5543-5554$

(24) Ravenscroft, N.; Walker, S. G.; Dutton, G. G. S.; Smit, J. J. Bacteriol. 1991, 173, 5677-5684.

(25) Merker R. I.; Smit J. Appl. Environ. Microbiol. 1988, 54, 20782085.

(26) Liu Y.; Fang H. H. P. Crit. Rev. Environ. Sci. Technol. 2003, 33, $237-273$. in aqueous suspensions. Characterization is based on element- and chemical-state-specific imaging of these suspensions near the $\mathrm{Al} \mathrm{K}$-edge at a $50 \mathrm{~nm}$ resolution and an analysis of $\mathrm{Al} \mathrm{K}$-edge XANES spectral features, which are sensitive to the Al first-neighbor coordination environment as well as to differences in the medium-range $(<5 \AA)$ chemical environment of Al. The ability of STXM analysis to provide both element-specific maps and XANES spectra at the K- and L-edges of a variety of important elements in colloidal particle mixtures at a very high spatial resolution in the presence of water results in a unique capability for characterizing colloidal suspensions, including biocolloid-mineral mixtures under hydrous conditions. Additional C K-edge and Al K-edge STXM studies undertaken on a mixture of Caulobacter crescentus and Al-containing minerals demonstrated the presence of loosely associated mineral-bacteria flocs and implied the potential role of extracellular polysaccharides in facilitating the formation of these mineral-bacteria aggregates. Further studies on bacteria-mineral interactions and their impact on the molecular-level speciation and colloid-facilitated mobility of pollutants such as arsenic are in progress and will be communicated in future publications.

Acknowledgment. We gratefully acknowledge the support of NSF Grant CHE-0089215 (Stanford University CRAEMS on Chemical and Microbial Interactions at Environmental Interfaces) as well as EPA STAR Grant R827634. K.B. also acknowledges partial support from a Lavoisier fellowship from the French Foreign Ministry. The work at the ALS and ALS BL 11.0.2 was supported in part by the Director, Office of Science, Office of Basic Energy Sciences, Division of Materials Sciences, and Division of Chemical Sciences, Geosciences, and Biosciences of the U.S. Department of Energy at Lawrence Berkeley National Laboratory under Contract No. DEAC03-76SF00098. We thank Dr. Mary Gilles, Sirine Fakra, and other staff members of ALS beamline 11.0.2 for their assistance during STXM experiments. The clay minerals used in these experiments were kindly provided by Jeffrey Catalano of Stanford University. We also thank Bob Jones of Stanford University for help in taking the high-resolution SEM image of dry corundum particles.

LA048558Y 